\title{
National Identity through Musical and Poetic of Albanian Lullaby
}

\author{
Majlinda Hala \\ ME. Ongoing PHD, Arts Surriculum Development Specialist, \\ Institute for Educational Development, Tirana, Albania \\ m2hala@yahoo.com; m2hala@hotmail.com
}

\section{Doi:10.5901/ajis.2013.v2n9p235}

\begin{abstract}
This topic is intended to bring to the attention of the audience lullabies for children, as part of an individual and family life cycle and representation part of the national identity. Lullabies in Albanian folklore are developed through expressive music means, ranging from the minimal level of poetic and melodic possibilities of music and language. They develop reaching up to crystallized musical and literary forms, to authentic lullabies and songs sung under the function of lullabies and that suit more or less to lulls condition. Lullaby composers have carefully created a harmony between the literary language content with the dialectical of provinces where the lullabies are sang. Metric, strophic and prosodic features of lullabies show that they excel while using the resonant effects that offers the Albanian language, this in accordance with their melody, a compatibility that to be useful is dictated by some specific features that dictates the function of this genre. In conclusion, such examples show that in general lullabies retain a powerful emotional conductivity which stems from the idea of a lullaby sang by the mother. Thus, they are represented on both the melodious side as well as the rhythmic and poetic side through a frequent repetition of the same motif, with a small vocal stretch and without distant intervals breakthroughs finding distinctive characteristics and features from one geographical area to another.
\end{abstract}

Keywords: Iullaby, national identity, expressive tools, metric, prosodic and strophic features, motive.

Cradle songs or lullabies are an important part of values of the Albanian folklore and constitute an important asset of creativity and musical poetic lyricism of Albanian people. First of all, they are considered as a clear expression of national identity and of undeniable wealth by brining, through this kind of literary poetry and music, lullabies examples that show that, lullabies in gjeneral preserve very powerful emocional conductivity; substantial variety formed over many centuries and studied as a separate type of poetry that contains human and social values as the real reflection of these relations. All lullabies, generally, maintain a strong emotional conductivity which stems from the idea of the lullabe, making it pleasant for children by conducting to children its melodic and rhythmic and poetic character. Secondly, lullabies are known for having stylish-structural expressive tools in the texts used for them, defined by the mother's desire to artistically communicate with her child by using poetic figures as comparison, metaphor, epithet etc., and by reaching the ultimate goal of putting the child to sleep, as well as expressing all the wishes for the welfare of the child, with all the virtues and values that should characterize the child. Thirdly, lulabies are known for their musical and expressive means and different melodic features that are conveyed not only by one regional area to another, but also within the province due to the simplicity of musical construction, melodic expansion that is generally limited, with little exceptions, their recitativemelodic character, the soft tone of the voice, the sweet and peaceful sounds, peaceful and playful rhythms, musical ornaments, etc. Fourth, lullabies and not only them, are a clear expression of national identity, and an undeniable wealth brought by this kind of literary and musical lyricism.

The combination of literary and musical elements, sung with such simplicity, love and mastery of the mother, sister, grandmother or a relative of the child, have completed the main function of putting the baby to sleep. Synchronisation of these two elements of verse and melody has managed to preserve their double-functionality (artistic and utilitarian) (Daja $F, 1982$ ). Lullabies are developed in a very simple, clear, scalable and consistent way through expressive tools ( Vasili K. - Doja A, 1990), which start from the minimal level of poetic-melodic possibilities of the language reaching up to crystallized musical-literature forms and getting to proper lullbies and songs sung under the function of lullabes, namely, to various lyric songs that fit more or less to [nanuritje] condition. Text and melody have an organic connection between them and do not function without each other. Often, the literary content and textes of lullabies are created taking care to create harmony between the literary content and melodic voice of the language or dialects of the language in those regions where lullabies are sang. Metric, prosodic and strophic features of the lullaby show that they stand for using the 
resonant effects that $s$ offered by the Albanian language in line with lullabies melody, a compatibility that to become usable, is dictated by certain traits that are define by such a genre like lullabies.

I. A clear expression of national identity through the content, which as per the artistic form and function that lullabies have forme through centuries by mothers, have created an assigned profile and today constitute a kind of folk poetry which continues be studied in many aspects such as literary, musical, content-like, social, psychological, aesthetic, all these as the development of human and social values and as a real reflection of these relations. Numerous developments, that place not only in the maternal psychological level but also in her sociological and economical level, have led to the creation of new lullabies based on new conditions, where the wishes of mothers vary depending on these conditions. A regional and geographical approach, from North to South, is pursued on those examples brought into the presented material.

II. Stylistic - structural expressive tools of lullabies lyrics. Lullabies are defined as separate type of the Albanian popular lyrics, as simple creations that throughout words, and later melody, aim to achieve the ultimate goal, putting the baby to sleep, but at the same time expressing the mother's desire to spiritually and intimately communicate with her child expressing also her wishes for the welfare of the child along with all the virtues and values that should characterize him/her. All the structural and stylistic range used in these creations, make these songs quite origjinal as both, their literary and musical arts perspective. In many studies examples, also in the detailed description of certain stylistic and struktural lullabies of various provinces of Albania that are used for this material, lullabies are presented as monologues between the mother and the child. The lullaby "Nina - nin përkuni djalin" (the lullaby 7 - Shkodër) (Daja F, 1982), has the form of an intimate poetic monologue. It conveys, with a warm lyricism, the universal feeling of mother's love for the child. The lullaby lyrics starts with the nina-nana, what is a liche for all cradle songs. The "character", to whom the mother runs the request or prayer on, is directed to care abort her child during the sleep (xhumë, o xhumë ku m'je vonue/ djalin tem ma ke harrue). Sleep, as in any lullaby, is here a personification, and roughly treated as God, which indicates the antiquity usage of the of these lullabies. The language used is simple, and proves that the beauty of art stands in siplicity. The literary figures used here are:

$\rightarrow$ Alliteration, which is located almost in every verse and gives rhythm to the poetry (hajde xhumë, ma merr me t'shpejtë);

$\rightarrow$ metaphorical epithet (arç i bardhë);

$\rightarrow$ antithesis (take flight, the bjerma again).

Strings are almost 8 syllable, what is also most used string in the Albanian folk creativity. The rhyme has no regular schedule. In poetry and strings with rhyme (të puthur) (xhumë, o xhumë ku m'je vonue/ djalin tem ma ke harrue) or internal rhyme (merre vrap e bjerma prapë). The emphasis is placed into syllables 1, 2, 4,6, 8 of the string. The structure of this lullaby is 8 syllable. The text of this lullaby is famous for the dialect of the language of the city where the lullaby originated. For example: the word xhum - gjumë (sleep); kij - qingj; berma- bjerma are exactly in the 2nd and 9th verse.

The lullaby "Nina - nina po t'perkuni" (example $\mathrm{nr} 23$ - from Tropojë) (Daja F, 1982), essentially expresses the desire of the mother that her son make a comfortable sleep and grows in harmony with the surrounding environment. The sleep, in this case, is a personification. Although in this case the lyrics is not very much emocional, but mostly descriptive, its values lie in the aesthetic idea to express what makes the life of child that is sleeping, like playing in the gardens and collecting flowers to bring home, what constitute a universal metaphor and which stands as message for the renewal of the human society. The verse is tradicional one, 8 syllable, and with emphasis on the 3-7 syllable of the verse.

In the lullaby "Po vjen xhumi tuj mi vet-o" (example nr 32 - from Kaçanik, Kosovë) (Daja F, 1982), we have an excellent metaphor, where the author is a master of using exact strings. The most beautiful finding in poetry is the creation of the figure of the sleep. Sleep has come and is asking: A ka ra Vetoni me fjetë? (Did Veton yet go to sleep?) in the second two lines of the verse, without a stylistic lord, the answer is affirmed saying that the actions of the child are normal. This lullaby is sang at the beginning of the sleep while the child is persuaded and positively motivated by declaring that the child is among those regular children that sleep on time. As far as the repetition of the main motif in here, it seems that the emphasis of the same message, gets richer through changes of poetic throught. Repetition of the same motif makes the lullaby more perceptible to the child, while the aim of this lullaby is to create a pleasant atmosphere. A characteristic of this lullaby is that the mother itself represent a different character from other lullabies by personalizing it to her child (to Veton). 
The verse is traditional one, 8 syllable, and with emphasis on the 1-5 syllable of the verse. The song is short and there is only one verse where the idea comes complete.

The lullaby "Nini - no, nini - no" (Example Nr 52, from Vashaj - Elbasan), (Daja F, 1982), gives a clear picture of Albanian women with a rich inner world and with many moral values. She is willing to sacrifice for others, and also she expresses her love and care to her creatures. To the mother, the child is like a saint, whether it is boy or girl, and every mother has their own way of expressing feelings and wishings. To the son, she wishes a long life, to be brave, wise, honest and respected by others; and to the daughter, she wishes to grow healthy and beautiful. Here, in this lullaby, the mother sings to her daughter, therefore the lyrics hav stronger messages than in the previous ones. She does not spare beautiful comparisons for her daughter, comparing her to the infinite beauties of the nature. Comparing her daughter to the bud flower serves to emphasize the delicacy, freshness and beauty of the child. The metaphor red-cheek expresses the wish of the mother for her daughter to be healthy, because for the people (in folklore) beng healthy means being beautiful. This lullaby has at the end of each verse the supporting vowel $\mathbf{0}$, which gives rhythm to the verses. Here, we dont find the same of syllables in the verses, and the rhyme is $A B C A B C$.

In another lullaby "Nina - nana more bir", example $n r$ 89,(Daja F, 1982), from Korçë, for the mother, seeping means being peaceful, healthy, in good state, growth, and this shows clearly in the popular lyric (sleep because it is good for your health). The mother, aparat from giving love to her child, also gives him/her security, what is essential for a healthy growth of the child (because mom does not let your hand alone... later I will come and wake you up). It is interesting how popular wisdom coincides with modern theories on child psychology. Here, the mother's desire for her child is expressed through idioms (may be river takes ways his/her evil). In this lullaby, the rhyme is AABB, the verse is 8-syllables one, while the accents falls into syllables $1,3,6,8$. The figures that make this lyllaby important are: personification (sleep), metaphors (I am your soul) and alliteration.

The lullaby "Nina - nina djalin -o" Example $\mathrm{nr} 68$ (Daja F, 1982). This lullaby is rich with literary figuration or figurative language. We have here personification (to falling asleep), idioms (may be river takes ways his/her evil), escalation (may be evils will be taken by the river, may be the sea destroyes them), comparisons (my son is as brave as (dovleti). Strings here are 8 - syllable, while the rhym is aligned.

The to last lullabies to analyse "Llaj - Ilaj djalën -o" Example nr 96 (from Kudhës - Vlorë) and "Llaj - Ilaj e nina - nana" Example nr 97 (from Vuno - Vlorë), (Daja F, 1982). In the first lyllaby , the metaphor builds on the idea of the future family that will create the son. It, aesthetically describes his future bride like an eel in the water-stream, beautiful, energetic, and good enough to be the ideal future wife, at the same time to e strong enough to take care of the households. These wishes make the essence of human aspiration to design a satisfying future. The metaphor here, as the central figure, idolizes the woman as an aesthetic value. The verse has 8 syllables with an emphasis 1-7 syllable, with a coincide rhyme AA-BB.

While in the second lullaby, which aims to accompany the child at the moment belore the child sleeps, the mother wishes on the future profile of her son. The musicality of the first verse, where is set the spiritual mother-son relationship, will be followed by a second verse (the little one in nappy) which with gives empathy for the fragole status of the child as "little" and wrapped in his nappy (diapers) as tight. This idea is further strengthened in the third and fourth verse, where the curse on the nappy, in contrast, becomes the antithesis to sleep as a phenomenon that enhances and beautifies human being. The comparisons that are used here may you become big as your friends, expresses the perspektive of the mother for her child, wishing her child to be peaceful and white like lamb, wise and powerful as the dragon, and being always the best among his friends. The verses here are 8-syllables, with an emphasis on the 3-7 syllable, and being completed here with the extra vowel -0 at the end of the line.

Very interesting is the Iyllaby of the Italian Arbëresh - "Nina - nana"Example nr 113, (Daja F, 1982), Castriregio, Calabria - Italy, which is an evidence of how the Arberesh of Italy fanatically preserved the Albanian language. The Arbëresh woman expresses her love to her creation, through her desire for the child to sleep long, because sleep is healthy (may you sleep a lot - metaphor). The connection with the child, the mother expresses through the pronoun MY (my son) breastfeeding. The anafora hoj , through which start all the verses, gives rhythm and sweetness to the poetry. The rhyme (puthur), the verse is 8-syllable. Similarly as in the previous lullable, alliteration is missing here. 
III. Expressive musical tools and various melodic characteristics, are conveyed in different ways not only from one territory to another, but also within one region. The simplicity of the music building, the generally limited melodic extention, mostly by the genre that they represent, with little differences from time to tme, and more widely when they pass within the octav interval, soft timbre, the sweet and peaceful melody, playful and peaceful rythms and musical ornamentation generally constitute melody Lullaby. Through the analysis made to some musical examples in this paper, we will look at lullaby characteristics in terms of their structure, rhythm in which they are sung, melody, melodic ornaments, all these characteristics that make them different from one territory to another.

III 1. Musical forms, which are easy, and we find them sometime built in the formo $f$ music periods and in the form of musical sentences. Generally, we find lullabies built in 2,3,4, or 2, 3, 4 musical periods. The second musical sentences or even the following ones are repeated and are similar to each new verse. But within this similarity we see characteristic changes that distinguish and make them distinct from each other because of interpretation or regjional melodic characteristics. Despite the very small changes observed during musical construction of the lullaby melodi, each repetition of musical phrases and periods generally ends with reinforcement of the musical thought in the form a cadence support. Very special by its structural building, from this analysis, we distinguish an Italy Arbëresh lullaby "Nina - nana" Castriregio, Calabria - Italy, which is particular as far as regards the presentation of its musical form. This lullaby is composed of three (3) piece of music. The first part consists of two (2) musical period and cadence supports. The second part consists of one (1) musical period, which includes three (3) musical phrases, and the cadence support. The third part, consists of two (2) musical periods, which contains two (2) musical phrases, and the cadence support. A general characteristic of the lullaby is that it maintains a complete final rhyme, in the periods where music has long cadences associated with short breaks $1 / 4$. With a slow rhythmic movements it preserves a rish with figures accent rhythmic that fits to the syllable process of the word. This lullaby has a full diatonic harmony full with pure light, which appears in the motif, which begins with a major key and ends at the end of the sentence with minor tonality of musical note LA (A), where the IInd grade, more specifically the musical note $\mathrm{SI}(\mathrm{H})$ is lacking in structure from the beginning to the end. The motif of the start, is repeated only in one case, when the musical note is in the middle, but not complete (only the first steps, because the motif is composed of two musical measures). The form of th elullaby is divided in accordance with the verse and poetic word, as well as with the emotions they convey, while maintaining the key features to the end of the first sentence, such as:

1. Melo-rhythmic figures

2. The transition from major to minor

3. Regularity of musical measures

4. The crown and ornamental sounds

III 2. As far as musical rhythms regards, lullabies are presented to us with a variety of rhythms, from simple rhythms, complecated once and to those ad libitum or differently, free rhytms. Of course, the musical rhythms we findin lullabies are connected harmoniously with the poetic lyrics content and with the purpose that the mother has putting the child to sleep. Oftne, rhythms are associated with the emotional conditions that the mother has during singing the song for the child. It happens that the ratio between musical periods can be oblique and uneven, because it maintains the same number of steps, regardless of the unique rhythm metric $2 / 4$. This happens because the melody is imposed basen on the length of poetic verse. In any other lullaby, the mixed rhythm 7/16, is set to the fact that the interpreter will show that their actions were within notes $1 / 16$, and another reason is that the sound of names $1 / 16$ should match the test, emphasizing every word, in this case the name of the person (Veton), which unlikely from other lullabies that are anonymous and are generally sung to children. Sometimes, even though lullabies have a mixed pace, they have a stable rhythmic regularity and a regular musical thought of the verse. Another example of the mixed rhythm $2+2+2+3$, separated by transcripter, shows that every syllable gets an accent which, despite being part of the word, gets the meaning/importance from sullabies (Ilaj-Ilaj-Ilaj-e...) etc. The meaning is not only poetic, not only visual, but above all emotional, expressive and clarifying the idea, using lovely words (llaj - Ilaj) that mitigate and sweetent the idea of the melody.

III 3. The lullaby melody is generally simple and they have a developing character in terms of melody, rhythm and harmony being sang not only alone but also in grup with others or instrumentals. Sometimes, because of the area they come from, we have a masterful accordance with the verses, in terms of the accent melo rhythmic, which preserve the typical dialect of the North region. The character of the lullaby melody in the north (example 23) contains ornamental sounds such as groups, açakatura, inferior and double mordenti, 
superior açakatura, these show that the melody of the song retains and conveys instrumental elements as well as vocal ones that immitate the lute instrument. In another example, we see the link between sounds and words, and melizamtike links where over a single sullable there come around manye sounds (example 68). In examples 96 and 97 we have the singing of the solo lulabies of these regjion, we call it also a phenomenon, because the singing in the south Albania is famous for singing in gorup or differently called polyphonia. The lullaby, taking into account its specifik that is sang in solo, and the mother that sinus the lullaby in this regjion, preserves the role of the taker that is part fo the polyphony sonës of this area, and she starts and finishes her song, alone. As far as regards the harmony, the song (example 96) sits in harmonious piedestal (ostino) in the musical note SI that, indipendently it has no ISO, and is not part of the ISO - Polyphonic songs, it gives the impression that ISO is being sang in the background. This gives more harmoniousy and enriches the song, no matter how seemingly built on the basis of three sounds SI; DO \#; Re \#; Si; ( $\mathrm{H}$; $\left.\mathrm{Cis}^{\text {is; }} \mathrm{Dis} ; \mathrm{H}\right)$.

Melodic extension (example 97) is in the range of pure kuartet of the interval $\left(4 \mathrm{P}=2^{1 / 2} \mathrm{~T}\right)$ more exactly in the musical notes Re and $L a(D$ and $A)$, or $L a$ and $\operatorname{Re}(A$ and $D)$, despite that she starts with the musical note DO $(C)$, the ostinato base is the note LA (A) which is a fature of the music of the south. This is a simple lullaby, but the decrease in the pure $\left(4 P=2^{1 / 2} T\right)$, in notes RE and $L A(D$ and $A)$ it comes a bit un-prepared, but still it is very organic and origjinal and natyral. She forms a melos, supported in the pedal $L A(A)$, that is enriched with the set of notes pure $\left(4 \mathrm{P}=2^{1 / 2} \mathrm{~T}\right)$ in notes $\mathrm{LA}$; SI; DO; RE; $(A ; H ; C ; D)$ specifically $1 T+1 / 2 T+1 \mathrm{~T}$. Thi sis intertwined with rhytmic figures while adapting to the sullable process of the words.

This lullaby has a narrative character, expresses spiritual tranquility of the the mother and her wish that the son becomes as strong and hardworking fas his riends. These features are clearly expressed through literary figures as lambs, dragon, etc.

Ninulla (example 52) is on of those not very frequent lullabies that is sung to girls, what speaks of a patriarchal society what is mostly transmitted through conservation of her delicacy and fragility and illustrated through elegant melody that is noticed in the first motif. This example differs from many other lullabies because it start with the pure kuart interval, that is supposed to have the basic musical notes of the lullaby, like Ml; LA;. and also enriched with a solution of the second measure, in (nëntonikë) with a new musical note, a sound which prepared through crown a reversal of the motif. From its melorhythm, this motif varies by using the values 1/16 (third measure) and adding also ornamental sounds (melizmatik). This happens because of the poetic development begins and considering the idea that the mother is singing to her daughter, like for example:

nina - nana, nina - nana

zënë moj, gjumi moj,

vajzën 0.

Although the word "moj" is not a correct word in daily communication, here it is used in a sweet Track with regard to the ethics of communication daily, here is used describining careness and underlining the gender of the child.

\section{Conclusions}

Through a detailed research of lullabies we clearly see that the emotional world of the Albanian woman transmitts, hrough literary and musical elements, complete messages aimed not only at her children but also aiming to communicate with the intention and desire of the mother to project her child in the future as living in a happy family and society, and having the best values of life. Also, in their aesthetic terms, lullabies gain special value because of their artistic values of the singing-person, in this case the mother, as well as family and social traditions. Using expressive means, lullabies has diversified using different epithets, metaphors, comparisons. Thus, lullabies make a very interesting and important case to study by young researchers, mainly focusing on:

- Folklore and ethnological studies, the first folk lobes of literary and musical creation, what creates the resource of human life in all aspects,

$\rightarrow$ Psychological studies,

$\rightarrow$ Sociological studies,

- Recognition of the indisputable values of literature and music that includes this kind of poetry that is the lullaby,

- Creating of songs for children, based on best folk music characteristics of our tradition.

$\rightarrow$ Discovering the identity, tradition and special features of that part of our early culture from different areas of Albania. 


\section{References}

Daja F, "Songs and games for children" (1982), Academy of Sciences of the RPS of Albania, Institute of Culture, Tirana.

Vasili K. - Doja A, "Popular lyrics" Cultural Heritage of Albanian People, Albanian Folklore, 4th Edition, (1990), Academy of Sciences of RPS of Albania, Tirana. 